報丈一3

䫝量分析計によるアンモニア合成循環ガス中

のアルゴンßびメタンの分析

土屋利一

(家工亲試験所)

1.はしがき.

アンモニア合成原料ガスはN 2 容， $H_{2}$ 了容から成る混合ガスで两る。 この混合ガスを触媒を充填した合成管を含む一環の合成系內を，粑えず

新原料ガスを補粭しながら高压の下で得環させて合成を行う。又，直列に つほりだ数段の合成管に1000 気压前後の高压で系料ガスを送つてアンモ二 アを合成し，最後に反応しなかったガスを放出する型式もある。原料ガス は出来るだけ秋粹であることが合成能辛を上げる爲に必要である。N

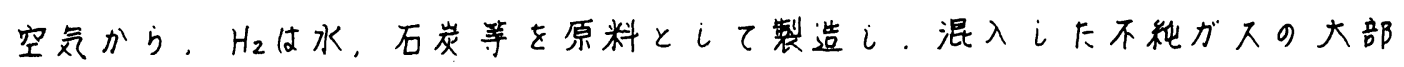
分を除去て、 $N_{2}$ / 容。 $H_{2} 3$ 容の割合になる妳下泿合 $i$ 上ものを合成系粒 に送る。こつでN $N_{2} と H_{2}$ とは $N H_{3}$ となつてとり出されるから，粑えず新 に吹き这まれる原料ガス中下含まれる微量の $\mathrm{CH}_{4}$ ，A等は不活性原る虎に

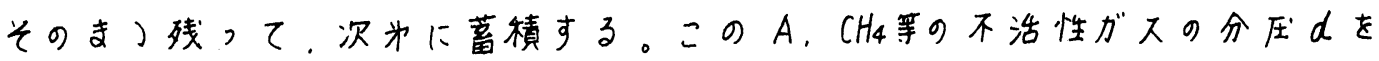
含む全压Pの混合がスの反底速度は，全压が $P\left(1-\frac{d}{P}\right)^{2} に$ 相当する紲原料 ガスの反応速度に等しりと云はれる。即方不活性ガスが含有されると单な る $\mathrm{N}_{2}$ と $\mathrm{H}_{2}$ との分压の低下以上の悪影響を生ずるのである。路つて任意 下瞬间下於ける合成系內のガスの粗成を道ちに知ることが出来れば，必要 に応して速かに道当を制御が行えるから合成前事を高める上に甚だ望まし い。刻マのガスの粗成を知る方法として，時间の㩧れが少い点。Aの分析 が可能である点等を考虍に入れると筫量亦析計による万法が道当してるる 称下思はれる。今回アンモニア合成諸会社の各工場の合成系粒のパージガ ス試料を入手し得下ので、これ等について算量分析計によつて主として $\mathrm{CH}_{4}$ Aを分析した結果を報告する。

\title{
2. 定量方法
}

算量分析計によつて定量分析を行う瓜には試料中下含まれる各成分ガ六

1)柴田勝太郎化学肥料㫫妻 3 P. 20 
の分圧が、各成分の与える質量スぺクトルの强度に比例することが必要で ある。試料ガスを分子流としてイオン源に送入する时この條件が满足され ることが知られている.?

一般下a，b，……等数成分より成了混合がスの $m / e=n （ m$ は水来原 子算量をけとした時のイオンの算量，已は童位電荷)なるスペクトルの強 度江は，上記の條件の下に於ては。各成分がスが各、の分压で罩独に存在 する時に与える $\mathrm{m} / \mathrm{e}=n$ なるスぺクトル強度の和となる。從つて前以て

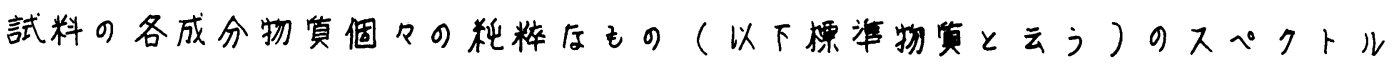
強度を上の條件の下で测定えて，光の单位压力当りの $\mathrm{m} / \mathrm{e}=n$ のスプクト

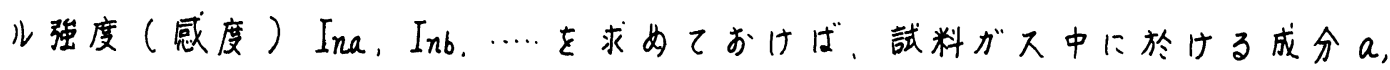

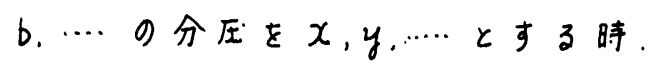

$$
I_{n}=x I_{n a}+y I_{n b}+\cdots \cdots
$$

が成立する。一物賞につりて何本もスペクトルが出るのが普通であるから 同妳の式が他の $m / e$ についても得られる。成分数と同にだけのスぺクト

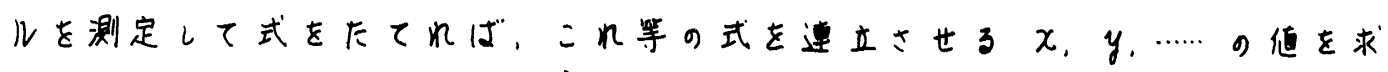
めること，即方分析が出来る

本都の分析资料中下は $\mathrm{H}_{2} 、 \mathrm{CH}_{4} 、 \mathrm{~N}_{2} 、 A$ だが合まれていたから $\mathrm{m} / \mathrm{e}$ して2，16，28，40をとれば上式の右边は一项だけとたつて苚である。

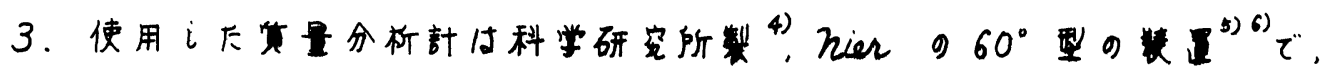

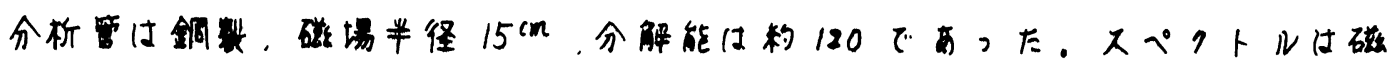

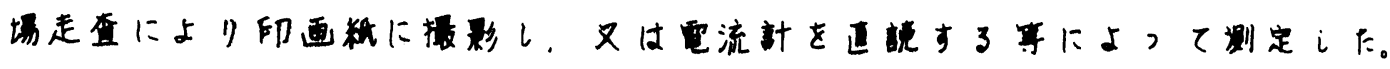

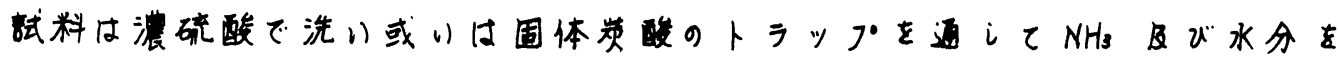
除き，更にKOHの上を通し下ものを水銀压力計でピペットにはかりとり， これを試料溜めに送つて分析i下。䄪 25 の 試料溜め下 $0.1 \sim 0.2 \mathrm{~mm} \mathrm{Hg}$ g 試料をとり，これを粎 $0.01 \mathrm{~mm}$ 道径の小孔を通じてイオシ源に入した。こ れによつて生ずる試料溜めのガス压の減少は水来ガスの場合で、時间に \%に建したかつた。試料中にはCOは黑いから゙ m/e=28のスへフトルを

2) R.E. Honig,' J. Appl. Phys. 16 (1945) 646

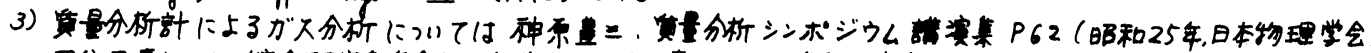

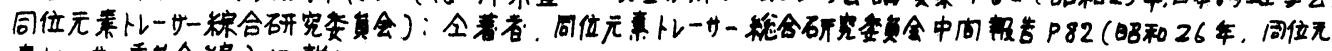

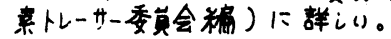

4) 杉本研究宝の御好意に上3. 5) a.0. Nier. Reo. Sci. h h th 18 (1947) 398

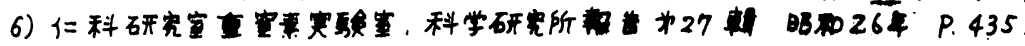

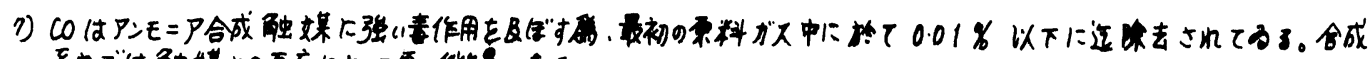
采内では触媒との反応によつて更に微争となる。 


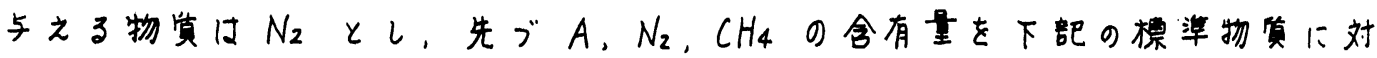
して決定し、残りを $H_{2}$ と深。

棉草物实は次の妳にして造った。

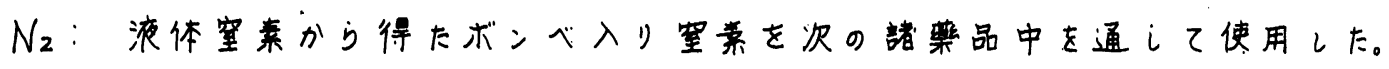

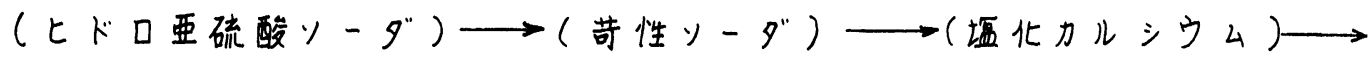
$($ 濃硫酸 $) \longrightarrow\left(800^{\circ} \mathrm{C}\right.$ の遇元銅 $) \longrightarrow($ 五酸化燐) $\longrightarrow($ 鎾化カルシウ 4)

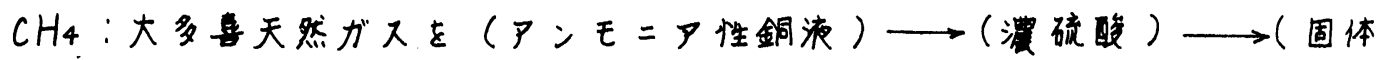

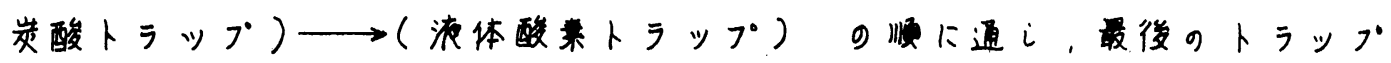
に溜った液体を常温に决し，溜出するガスの中，初溜及染榴分を捨て主 溜分をとつた。

A : 市椇「タカチ木」製。「柾アルゴン」

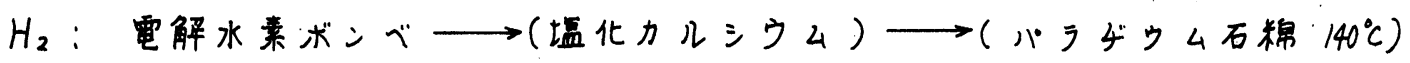
$\longrightarrow$ (五酸化燐)

分析䊅果はすでて以上の標泮物寅に相対的な值となる。

標渠物赏を湜合して造つ下粗成铁知の試料について分析した粘果を为 1 表に示す。全く同妳の方法で未知試料につりて分析を $3 \sim 5$ 回くりかえi，

第 1 光

\begin{tabular}{|l|c|c|c|c|}
\hline & $\mathrm{CH}_{4}$ & $\mathrm{~N}_{2}$ & $\mathrm{~A}$ & $\mathrm{H}_{2}$ \\
\hline 跃知試料粗成 & 16.31 & 34.30 & 14.49 & 34.84 \\
\hline 分析結果 I & 16.18 & 33.09 & 14.26 & 36.41 \\
\hline 差 $\Delta \quad \mathrm{I}$ & -0.13 & -1.21 & -0.23 & +1.57 \\
\hline 分析結果 $\mathbb{I}$ & 15.75 & 35.58 & 14.54 & 34.13 \\
\hline 差 $\Delta \quad \mathbb{I}$ & -0.56 & +1.28 & +0.05 & -0.71 \\
\hline
\end{tabular}

平均をとつて得下分析䊅果をアンモ二ア合成㸴料がの制造オ式に徙つて 分颣したものがオ2奉である。表中の值は\%で西る。標隼試料に对し为 1 表と同程度の誤差があると思はれる。

4。为2表を検討する。为 7.8 列下夫年 $\mathrm{H}_{2} / \mathrm{N}_{2}$ 及び $\mathrm{H}_{2} / \mathrm{N}_{2}+A$ の值を揭 げた。 $H_{2} / N_{2}$ はるであることが空ましい。光にる如く大多数の場合はこ

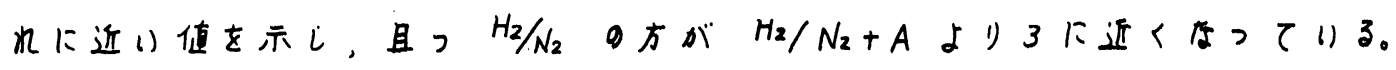

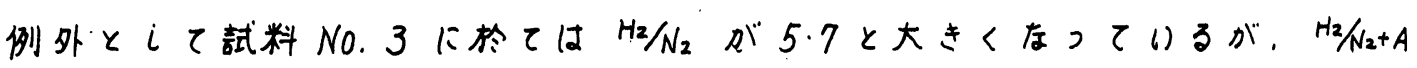


第

\begin{tabular}{|c|c|c|c|c|c|c|c|c|c|}
\hline & 試料畕号 & A & $\mathrm{N}_{2}$ & $\mathrm{CH}_{4}$ & $\mathrm{H}_{2}$ & $\mathrm{H}_{2} / \mathrm{N}_{2}$ & $\mathrm{H}_{2} / \mathrm{N}_{2}+\mathrm{A}$ & $\mathrm{CH}_{4} / \mathrm{A}$ \\
\hline \multirow{2}{*}{\multicolumn{2}{|c|}{$\begin{array}{l}\text { 電 } \\
\text { 解 } \\
\text { 法 }\end{array}$}} & 1 & 2.2 & 23.9 & 0 & 73.9 & 3.1 & $z \cdot 8$ & 0 \\
\hline & & 2 & $1 \cdot 2$ & 26.4 & 0 & 72.4 & $2 \cdot 8$ & 2.6 & 0 \\
\hline \multirow{2}{*}{ ガ } & 水 & 3 & 9.6 & 12.2 & 8.2 & 70.0 & 5.7 & $3 \cdot 2$ & 0.9 \\
\hline & $\begin{array}{l}\text { 性 } \\
\text { ガ }\end{array}$ & 4 & 11.7 & $18 \cdot 6$ & 13.9 & 55.8. & 3.0 & 1.8 & 1.2 \\
\hline ス & ス & 5 & 6.3 & 25.4 & 5.6 & 62.7 & 2.5 & $2 \cdot 0$ & 0.9 \\
\hline & 法 & 6 & 2.7 & 29.5 & 31.1 & 36.4 & 1.2 & 1.1 & 11.5 \\
\hline \multirow{3}{*}{ 法 } & 旁 & 7 & 3.9 & 27.7 & 10.9 & 57.5 & 2.1 & 1.8 & 2.8 \\
\hline & $\frac{1}{1}$ & 8 & 6.3 & 19.1 & 26.4 & 48.2 & 2.5 & 1.9 & $4 \cdot 2$ \\
\hline & & 9 & 5.9 & 20.5 & $20 \cdot 3$ & 53.3 & $2 \cdot 6$ & 2.0 & 3.4 \\
\hline
\end{tabular}

值は3.2である。通常の化学分析では，分析操作によつて最後迄反庶世ず に残つた不活性ガスを叔と假定している。從ってこのエ場に於てのみは反 応するガスの粗成を監視する祭に不活性がスとしてAが存在することを考 兔せずに，不反応ガスの全部をN 2 と見做して操業していたと考えると。 この翼常に高い $\mathrm{H}_{2} / \mathrm{N}_{2}$ 值は説明される。

最後の列にCH4/Aの值を示した。こつで注意されることは原料の製法の 異るにつれてこの値が相異る三群に分れている点である。

为1群を后す電解法の場合，原料の期は水の電解で製造するので當然 $\mathrm{CH}_{4}$ は $0 \%$ である。1〜2\%のAは空気の波化分離で製するN 湜入し蓄樍したものである。文れ故このAの值が定常狀態に於けるもので あれば，吹き込んでやる $N_{2}$ 量及び关のA含量から，実際の合成設㒂に於て 不可避的に生ずるガス洩れの程度が判明する管である。

水性ガス法による为2群では試料N O . 6 を别にすればCH4/A の值は１前 後である。このオ法はコ一フスに空気を吹き込子燃焼さ世て温度を高好

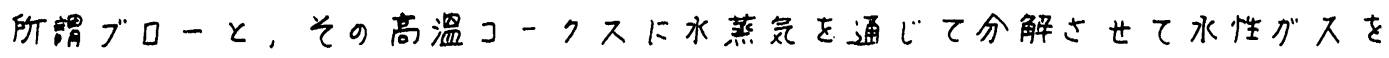
発生させるランとの二段階の操作を交互に行りN2を含むブローガスとN2 及び $H_{2}$ を含玉ランガスとを適当に混合してアンモ=ア合成に適する組成の ガスを造るのであるが、メタンはブロ一、ランの両段階に於てコークスの

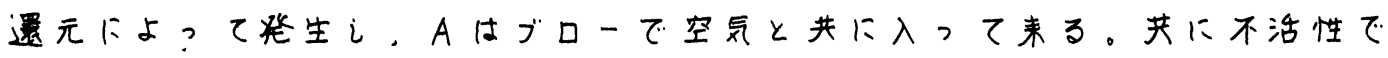
あるCH4 と・Aとの比は票料ガスに於ける值がそのまつパーヂガスに於ける 


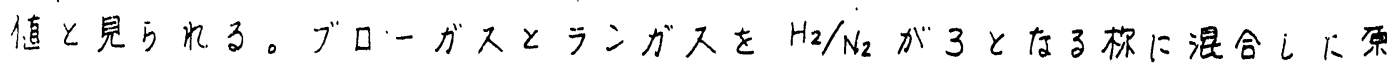

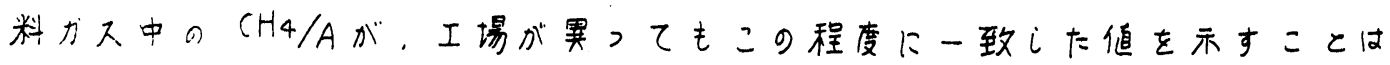

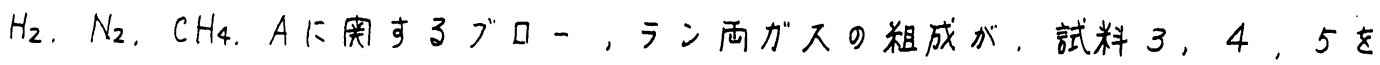
与えた各工場を通でて夫マ類似していることを想像させる。

为了群のウィンクラ一炉による方法の $\mathrm{CH}_{4} / \mathrm{A}$ 值は3〜4である。ウイン クラー法は原料岩として石岩，コ一ライト等を選び、水蒸気、空気及び酸 素を同時に吹き込んで，票料岩の燃燒による高温度の維持と水の分解とを 同時に連䊩的に行う。この方法によつて得た原料がスは水性がス法に比に はるかに多量のCH4を含有することが知的れている。Aは空気及び酸素と 共に入る。CH4/Aが似た值を示す点につりては水性ガスの暢合と同妳に考 えることが出来よう。

尚为2群の試料を与え下一工場の試料を䄪1年後に再び採取i，分析す る機会を得たが、C $\mathrm{CH}_{4} / \mathrm{A}$ 檤は禹者の場合 $10 \%$ 以內で一致、た。若i同一合 成設偖で，ある條件の下にCH4/A 值が常にこの程度に一定值を与えるなら 時々適当方方法でこの值を测定して確めておけば，通常の化学分析の比較 的简单な $\mathrm{CH}_{4}$ の定量を行つてA量の大体の見当をつけることが可能である かもしれない。この同題につりては更に実验をくりかえす必要がある。

5、以上は $\mathrm{CH}_{4} ， \mathrm{~A}$ 等が浱縮されて存在するパーダガスにつりての分析 結果であるが，ガス法による原料ガスにつりて，特に $\mathrm{CH}_{4}$ の定最が简易， 迟速，且つ定量的下行之れば，原料がスの粗成を乥の製造段階に於て制御 出来了から释済上甚だ好都合である。この妳な目的に工場で使用する复量 分析計に対にては， $0.1 \%$ 程度のCH4 が分析出来ること，堅宇で取报ひが 商便であること、出来ればスぺクトルが直䅐出来ること等が要求される。 分解能は20〜30位でよく $m / e=16$ に固定的に焦点を結び，イオン加速 電压，電子電流，電子加速電压等も固定的な裝置で十分である。尚スィッ チを切りかえる等して、期、 $N_{2} 、 A$ 等も分析出来几ば必要下応でてパーダ ガスの分析をも連䄯的に行えるから更に申に分ながう。

現在工場に於て操業中の南题に用する虎に触九得ない点があつた。試料 を惠与された日本化成工業株式会社、日東化学工業株式会社，日本水来工 業株式会社，東洋高压工業株式会社。東亚合成化学工業株式会社，昭和電 工株式会社の諸会社下感激する。

又, 東京工業試験所藤辰夫为四部長, 内田熙博士から㮔々御教示及び御 指導をいただいた。厚く感揤する次为です。 